\title{
Prolonged Amphetamine Treatments Cause Long-Term Decrease of Dopamine Uptake in Cultured Cells
}

\author{
Nafisa Ferdous ${ }^{4} \cdot$ Sirisha Kudumala $^{2} \cdot$ Serena Sossi $^{3} \cdot$ Lucia Carvelli $^{1,2,3}$ [D
}

Received: 16 September 2019 / Revised: 12 December 2019 / Accepted: 18 December 2019 / Published online: 27 December 2019

(c) The Author(s) 2019

\begin{abstract}
Amphetamine (AMPH) is a systemic stimulant used to treat a variety of diseases including Attention Deficit Hyperactive Disorder, narcolepsy and obesity. Previous data showed that by binding to catecholamine transporters, AMPH prevents the reuptake of the neurotransmitters dopamine (DA) and norepinephrine (NE). Because AMPH, either used therapeutically at final concentrations of $1-10 \mu \mathrm{M}$ or abused as recreational drug $(50-200 \mu \mathrm{M})$, is taken over long periods of time, we investigated the prolonged effects of this drug on the uptake of DA. We found that, in LLC-PK1 cells stably expressing the human DA transporter (hDAT), pretreatments with 1 or $50 \mu \mathrm{M}$ AMPH caused significant reduction in DA uptake right after the 15-h pretreatment. Remarkably, after 50 but not $1 \mu \mathrm{M}$ AMPH pretreatment, we observed a significant reduction in DA uptake also after one, two or three cell divisions. To test whether these long-term effects induced by AMPH where conserved in a model comparable to primordial neuronal cells and native neurons, we used the human neuroblastoma cell line SH-SY5Y cells, which were reported to endogenously express both hDAT and the NE transporter. Pretreatments with $50 \mu \mathrm{M}$ AMPH caused a significant reduction of DA uptake both right after $15 \mathrm{~h}$ and 3 cell divisions followed by neuro-differentiation with retinoic acid (RA) for 5 days. Under these same conditions, AMPH did not change the intracellular concentrations of ATP, ROS and cell viability suggesting, therefore, that the reduction in DA uptake was not cause by AMPH-induced toxicity. Interestingly, while $1 \mu \mathrm{M}$ AMPH did not cause long-term effects in the LLC-PK1 cells, in the SH-SY5Y cells, it decreased the DA uptake after one, two, but not three, cell divisions and 5-day RA differentiation. These data show that besides the well-known acute effects, AMPH can also produce long-term effects in vitro that are maintained during cell division and transmitted to the daughter cells.
\end{abstract}

\section{Introduction}

The neurotransmitters dopamine (DA) and norepinephrine (NE) belong to the catecholamine and phenylethylamine families of organic compounds and play an important role in fine-tuning a variety of animal behaviors such as movement, reward, cognition and attention. Following their synthesis,

Special Issue: In honor of Professor Michael Robinson.

Lucia Carvelli

lcarvelli@fau.edu

Brain Institute, Florida Atlantic University, Jupiter, FL, USA

2 Harriet L. Wilkes Honors College, Florida Atlantic University, FL, Jupiter, USA

3 Integrated Biology Program, Florida Atlantic University, FL, Boca Raton, USA

4 Department of Biomedical Science, University of North Dakota, Grand Forks, ND, USA
DA and NE are rapidly sequestered inside the neuronal vesicles by the vesicular monoamine transporter (VMAT), where they are packed until a depolarizing stimulus promotes the fusion of vesicles to the cellular membrane and the extracellular release of the neurotransmitters. In the synaptic cleft, DA and NE bind and activate their respective receptors and, thus, propagate dopaminergic and noradrenergic signaling. Although most of the released catecholamines diffuse away from the synapse [1], a good portion binds to the DA and/ or NE transporters (DAT and NET) [2, 3]. This step prevents further stimulation of the receptors. Therefore, DAT and NET control the intensity and the duration of the signal propagated by DA and NE. Moreover, when DAT moves DA inside the neurons, it causes cell-membrane depolarization affecting, therefore, neuronal excitability $[4,5]$.

All substances that induce dependence increase the extracellular concentration of DA and NE [6-8]. Amphetamine (AMPH) for example, performs this task through two different mechanisms. As the chemical structure of AMPH is 
very similar to that of DA and NE, AMPH is carried inside the neurons by DAT or NET preventing, therefore, the reuptake of these catecholamines [9]. Once inside the neurons, AMPH forces DA and NE out of the storage vesicles by acting on VMAT [10]. The subsequent increase of cytoplasmic DA/NE induces DAT or NET to work in reverse resulting in the efflux of DA/NE into the synaptic cleft [11, 12]. The overall effect is, therefore, the accumulation of larger amounts of extracellular DA/NE with respect to that obtained using DAT or NET inhibitors, such as cocaine or methylphenidate [13].

Previous reports demonstrated that acute and brief (1 min) treatments with AMPH increase the surface expression of DAT $[14,15]$, whereas brief repeated or longer treatments (5-60 min) cause a decrease of surface expression of DAT, as measured by reduced DA uptake activity and DAT-mediated inward currents [16-19]. These effects were thought most likely be due to reallocation of the transporter from the plasma membrane to intracellular compartments $[16,20$, 21], though German et al. reported that in vivo treatments with AMPH reduced the transport activity of murine striatal DAT without concomitant internalization of the transporter in ex vivo preparations [22].

The data mentioned above are examples of the several studies carried out over the last decades on the effects that acute AMPH treatments generate on DAT or NET activity. On the other hand, there are few data describing the effects generated by prolonged [23] AMPH treatments on the two transporters. Here we investigated the effects caused by 15 -h treatments with 1 or $50 \mu \mathrm{M}$ of AMPH on the uptake activity of hDAT heterologously expressed in the pig kidney cells or in the human neuroblastoma SH-SY5Y cells which endogenously express DAT and NET. We found that after $15 \mathrm{~h}$ treatment, both concentrations of AMPH reduced the accumulation of $\left[{ }^{3} \mathrm{H}\right] \mathrm{DA}$ inside LLC-PK1 and SH-SY5Y cells. Interestingly, this effect was inherited by the daughter cells up to three cell divisions in the LLC-PK1 cells treated with 50, but not $1 \mu \mathrm{M}$ AMPH, whereas in the SH-SY5Y cells, both doses caused a significant reduction of $\left[{ }^{3} \mathrm{H}\right] \mathrm{DA}$ uptake in daughter cells after three and two cell divisions, respectively. Taken together, these data suggest that AMPH causes long-lasting effects that can be maintained within the cell and inherited during mitosis.

\section{Methods}

\section{Cell Cultures}

LLC-PK1 cells stably transfected with hDAT were kindly provided by Dr. Roxanne Vaughan and James Foster (University of North Dakota). LLC-PK1 cells were maintained in $\alpha$-modified Eagle's medium (AMEM) containing $2 \mathrm{mM}$
L-glutamine and $200 \mu \mathrm{g} / \mathrm{mL}$ G418 sulfate; whereas SHSY5Y cells were grown in Dulbecco's Modified Eagle's Medium/F12 (DMEM). Both media were supplemented with $5 \%$ and $10 \%$ fetal bovine serum (FBS), respectively, and $1 \%$ penicillin/streptomycin. Cells were passaged according to the following protocol: after removing the media, cells were washed twice with $10 \mathrm{~mL}$ sterile phosphate buffer saline (PBS). After the PBS washes, $2 \mathrm{~mL}$ of trypsin solution was added to promote cell detachment from the flask. Trypsin was removed by aspiration and the cells were incubated in a $37^{\circ} \mathrm{C}$ incubator for 5 mins. Once cells detached, the cell suspension was gently mixed with $10 \mathrm{~mL}$ DMEM and collected in a $15 \mathrm{~mL}$ tube. Cell pellets were collected by centrifugation at $1500 \mathrm{rpm}$ at $4{ }^{\circ} \mathrm{C}$ for $5 \mathrm{~min}$, re-suspended in $1 \mathrm{~mL}$ fresh DMEM media and equally divided in T-75 flasks containing $10-15 \mathrm{~mL}$ media.

\section{Uptake Assays}

300,000 or 150,000 cells were seeded in $24-$ and $12-$, or 6-well plates, respectively. Different sizes of well-plates were used to accommodate the higher number of cells yielded after two and three cell divisions. Six-seven hours after being plated, cells were treated with $1 \mu \mathrm{M}, 50 \mu \mathrm{M}$ AMPH or control solution for $15 \mathrm{~h}$. After $15 \mathrm{~h}$, cells were washed three times with PBS and either used to measure $\left[{ }^{3} \mathrm{H}\right] \mathrm{DA}$ uptake or grown in fresh media to cross one, two or three cell divisions in order to perform uptake assay in daughter cells. Uptake assays were performed as previously published in Carvelli et al. [5]. Briefly, LLC-PK1 cells were washed three times with Krebs-Ringer HEPES (KRH) buffer. KRH containing $0.1 \mathrm{mM}$ tropolone, $0.1 \mathrm{mM}$ ascorbic acid and $0.1 \mathrm{mM}$ pargyline (KRH + TAP), was added to the wells to inhibit DA degradation and oxidation before performing the uptake assays. Finally, $\left[{ }^{3} \mathrm{H}\right] \mathrm{DA}$ (PerkinElmer) was added in each well to obtain a final concentration of 20 $\mathrm{nM}$. After $5 \mathrm{~min}$, cells were washed with cold $\mathrm{KRH}+\mathrm{TAP}$ three times and lysed with $1 \%$ triton solution. Lysates were collected in vials and radioactivity was counted using a $\beta$-counter. For SH-SY5Y cells, the experimental paradigm was similar to that utilized for LLC-PK1 cells. Cells plated in 24,12 , or 6 wells plates for $6-7 \mathrm{~h}$ were treated with 1 $\mu \mathrm{M}, 50 \mu \mathrm{M}$ AMPH or control solution for $15 \mathrm{~h}$. After the drug was washed off with three washes with PBS, one set of cells was immediately assayed for DA uptake. Another set of cells was let grow to pass one cell division as determined by cell counting. At this point, cells were treated with $10 \mu \mathrm{M}$ retinoic acid (RA) in low serum media (DMEM containing $1 \%$ FBS) for 5 days, during which media was replaced once with fresh media containing $10 \mu \mathrm{M}$ retinoic acid. Cells that went through two or three cells divisions also received the 5-day RA treatment before being assayed for $\left[{ }^{3} \mathrm{H}\right] \mathrm{DA}$ uptake as described above for the LLC-PK1 cells. 


\section{Elisa Experiments}

To investigate possible residue of AMPH inside the SHSY5Y cells, we used the Enzyme-linked Immunosorbent Assay (ELISA) kits (Abnova, TW). These consist of microwells coated with polyclonal anti-d-AMPH and d-AMPH conjugated to horseradish peroxidase (HRP). The principle of the assay is based on the competitive binding of AMPH and AMPH-HRP in proportion to their concentration in the reaction mixture. Cells were first detached with trypsin and collected by centrifugation. Then cells were washed with cold PBS three times, re-suspended in PBS to be sonicated (5 pulses for $5 \mathrm{~s}$ and then 10 pulses for $10 \mathrm{~s}$ ) and subjected to centrifugation at $1500 \times \mathrm{g}(4000 \mathrm{rpm})$ for $10 \mathrm{~min}$ at $2-8$ ${ }^{\circ} \mathrm{C}$ to remove cellular debris. Supernatants were collected and stored at $-20{ }^{\circ} \mathrm{C}$ or $-80{ }^{\circ} \mathrm{C}$ to avoid loss of bioactivity and contamination. On the day of the experiment, samples were brought to room temperature and $10 \mu \mathrm{L}$ of each sample, control and AMPH-treated, were incubated with $100 \mu \mathrm{L}$ dilution of enzyme (Horseradish peroxidase) labeled d-AMPH derivative in micro-plate wells which are coated with fixed amounts of oriented high affinity purified polyclonal antibody. Samples were incubated for $60 \mathrm{~min}$ at room temperature in the dark. After removing the enzyme conjugate and washing the wells with $200 \mu \mathrm{L}$ distilled water, the chromogenic substrate was added followed by an acid stop solution to cease the color produced from the substrate. Finally, the absorbance in each well was read within $1 \mathrm{~h}$ at a wavelength of $450 \mathrm{~nm}$.

\section{ATP and ROS Levels}

ATP changes were measured using the CellTiter-Glo Assay kit (Promega) following the protocol recommended in the kit. Briefly, 4000 and 8000 SH-SY5Y cells were plated in white opaque-walled 96-well plates (Falcon Cat. \# 353296) in DMEM/F12 media with $10 \%$ FBS and $1 \%$ PenStrep. After $24 \mathrm{~h}$, cells were treated with $50 \mu \mathrm{M}$ AMPH or control solution in fresh media for $15 \mathrm{~h}$ at $37^{\circ} \mathrm{C}$ in a $5 \% \mathrm{CO}_{2}$ incubator. Cells were washed twice with PBS and phenolred-free DMEM media was added to the cells. Cells were equilibrated at room temperature for about $30 \mathrm{~min}$ before adding the CellTiter-Glo reagents. The luminescent signal from each well, which is proportional to the amount of ATP, was measured using a microplate reader (BioTek Synergy H1) During each experiment, a standard curve was generated using increasing concentrations of ATP (0.025-0.25 $\mu \mathrm{M})$. Data from each experiment were normalized to control samples with the lower number of cells and analyzed for normality tests and statistical significance using GraphPad Prism 7.04 software.

Reactive Oxygen Species (ROS) were quantified by using the Invitrogen Molecular Probe $2^{\prime}, 7^{\prime}$-dichlorodihydroflorescein diacetate reconstituted in DMSO ( $\mathrm{H}_{2}$-DCFDA, Cat. \# D339). 10,000 or $20,000 \mathrm{SH}-$ SY5Y cells were plated in black 96 well plates (Costar \#3603) and treated with $50 \mu \mathrm{M}$ AMPH or control solution for $15 \mathrm{~h}$. Cells were washed twice with PBS and incubated with $50 \mu \mathrm{M} \mathrm{H}_{2}$-DCFDA for $30 \mathrm{~min}$ in phenol-red free and serum free DMEM at $37{ }^{\circ} \mathrm{C}$. The dye was removed, and fresh phenol-red free medium was added to the cells to recover. Cells treated with $50 \mu \mathrm{M}$ Luperox TBH $70 \times$ (Sigma Cat. \# 451839) for $1 \mathrm{~h}$ following $\mathrm{H}_{2}$-DCFDA were used as positive controls. Fluorescent intensity was measured with a microplate reader (BioTek Synergy H1) at excitation and emission wavelength of 480 and $530 \mathrm{~nm}$ respectively. Data from each experiment were normalized to control samples with the lower number of cells and analyzed for normality tests and statistical significance using GraphPad Prism 7.04 software.

\section{Statistics}

Data collected form each experiment were imported in Graphpad Prism software and evaluated for normality and statistical significance. Normality tests were performed using KS, Shapiro-Wilk or D'Agostino and Pearson omnibus tests. Statistical significance was performed using the parametric one-way ANOVA test and Bonferroni's Multiple Comparison post-test. Data were produced by three independent experiments, otherwise indicated, and in each experiment, samples were tested in triplicates or quadruplicates. See figure legends for number of repetitions in each experiment.

\section{Results}

\section{Prolonged Treatment with 50 but not $1 \mu \mathrm{M}$ Amphetamine Reduces Dopamine Uptake up to 3-Cell Divisions in hDAT Expressing LLC-PK1 Cells}

Previous data showed that AMPH pretreatments of 1 or 60 min enhanced or diminished the amount of DAT at the cell membrane, respectively $[14,15,19]$. Here, we investigated whether continuous and prolonged treatments with AMPH caused changes in DA uptake and for how long these changes were maintained. About $260 \mathrm{mg}$ of methamphetamine, taken as single dose by drug abusers, generate a pick of about 7.5 $\mu \mathrm{M}$ in the human blood [24] and concentrations seven times higher, i.e. $52 \mu \mathrm{M}$, in rodent brains [25]. Thus, we pretreated hDAT-expressing LLC-PK1 cells with $50 \mu \mathrm{M}$ AMPH or control solution for $15 \mathrm{~h}$ and, then, thoroughly washed the cells to remove the drug. In a subset of samples, $\left[{ }^{3} \mathrm{H}\right]$ DA uptake experiments were immediately 
performed to quantify the amount of $\left[{ }^{3} \mathrm{H}\right] \mathrm{DA}$ accumulated inside the cells. Another subset of cells was grown until their cell count was a value proximal to double, triple or quadruple of the initial number of cells counted before initiating the AMPH pretreatment. This indicates how many cell divisions the cells went through after the AMPH pretreatment. Cells tested right after 15-h AMPH pretreatment exhibited a statistically significant $37 \pm 3 \%$ reduction in $\left[{ }^{3} \mathrm{H}\right] \mathrm{DA}$ uptake with respect to samples pretreated with control solution (Fig. 1a; $* p<0.0001$; one-way ANOVA test). Both control- and AMPH-pretreated samples displayed almost no $\left[{ }^{3} \mathrm{H}\right] \mathrm{DA}$ uptake when the DAT inhibitor GBR12935 was included during the uptake assay, suggesting therefore that the accumulation of $\left[{ }^{3} \mathrm{H}\right] \mathrm{DA}$ inside these cells occurs exclusively through DAT. Interestingly, the other subsets of cells that went through 1, 2 or 3 cell divisions after the AMPH pretreatment also exhibited a statistically significant reduction in $\left[{ }^{3} \mathrm{H}\right] \mathrm{DA}$ uptake with respect to control-treated samples, $37 \pm 3 \%, 39 \pm 5 \%$ and $44 \pm 2 \%$, respectively, (Fig. $1 \mathrm{~b}-\mathrm{d} ; * \mathrm{p}<0.0001$; one-way ANOVA test). And, still under these conditions, the $\left[{ }^{3} \mathrm{H}\right]$ DA uptake was blocked by $10 \mu \mathrm{M}$ GBR 12935 .
Using previously published data $[24,25]$, we calculated that concentrations of AMPH for therapeutic use (5-30 mg) yield about 1-6 $\mu \mathrm{M}$ AMPH in the brain. Thus, we investigated whether $1 \mu \mathrm{M}$ AMPH produced effects similar to those obtained with $50 \mu \mathrm{M}$ AMPH. As shown in Fig. 1e, 1 $\mu \mathrm{M}$ AMPH caused a statistically significant $20 \pm 3 \%$ reduction in $\left[{ }^{3} \mathrm{H}\right] \mathrm{DA}$ uptake when the assay was performed right after the $15 \mathrm{~h}$ pretreatment with AMPH $(* \mathrm{p}<0.0001$; oneway ANOVA). However, no difference between controland AMPH-pretreatment was observed after the cells went through 1, 2 or 3 cell divisions (Fig. 1f-h). Taken together these data show that in LLC-PK1, $1 \mu \mathrm{M}$ AMPH causes short-lived changed in DA uptake, whereas $50 \mu \mathrm{M}$ AMPH produce a more penetrant effect which is maintained after three cell cycles.

\section{1 and $50 \mu \mathrm{M}$ Amphetamine Reduce Dopamine Uptake up to 3-Cell Divisions in SH-SY5Y}

Our initial experiments in LLC-PK1 cells showed that 1 or $50 \mu \mathrm{M}$ AMPH significantly reduced DA uptake in parent cells and this effect was transmitted in daughter cells only by $50 \mu \mathrm{M}$ AMPH. To test whether these long-term

50 $\mu \mathrm{M}$ AMPH/15-hour pre-treatment in hDAT-expressing LLC-PK1 cells

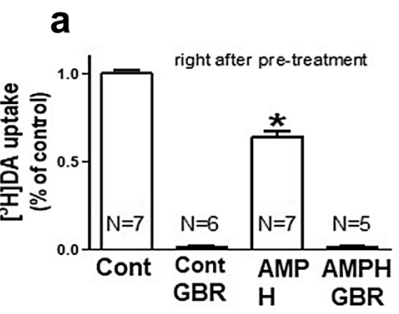

e

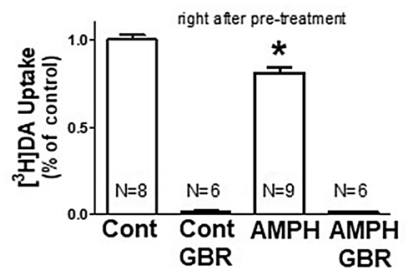

b

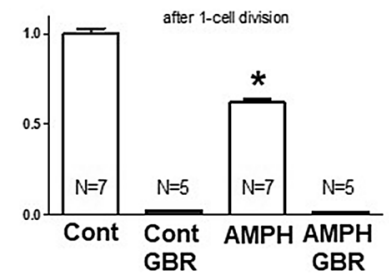

C

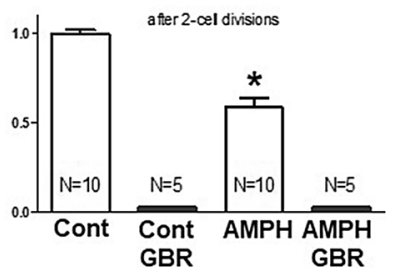

d

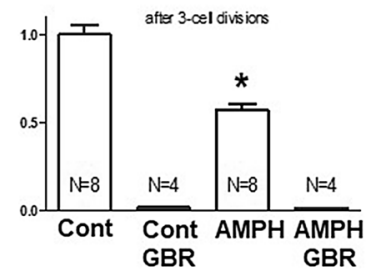

$1 \mu \mathrm{M} \mathrm{AMPH} / 15$-hour pre-treatment in hDAT-expressing $\mathrm{LLC}^{-\mathrm{PK}_{1}}$ cells

$\mathbf{f}$

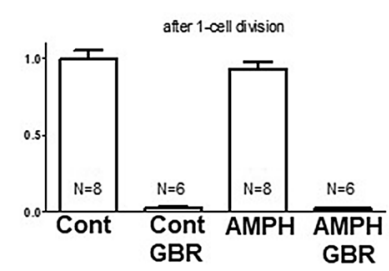

Fig. 1 Prolonged treatments with 50 but not $1 \mu \mathrm{M}$ amphetamine decrease DA uptake up to three cell divisions in LLC-PK1 cells stably expressing hDAT. Samples were pretreated with $50(\mathbf{a}-\mathbf{d}), 1(\mathbf{e}-\mathbf{h})$ $\mu \mathrm{M}$ amphetamine (AMPH) or control (Cont) solution for $15 \mathrm{~h}$. After 3 washes, cells were incubated for 5 min with $20 \mathrm{nM}\left[{ }^{3} \mathrm{H}\right] \mathrm{DA}$ alone or $\left.20 \mathrm{nM} \mathrm{[}{ }^{3} \mathrm{H}\right] \mathrm{DA}$ and $10 \mu \mathrm{M}$ GBR 12935. Pretreatments with $50 \mu \mathrm{M}$ AMPH caused a statistically significant reduction of $\left[{ }^{3} \mathrm{H}\right] \mathrm{DA}$ uptake with respect to samples pretreated with control solution both after $15 \mathrm{~h}$ and $1-3$ cell divisions (a-d). Pretreatments with $1 \mu \mathrm{M}$ AMPH caused a statistically significant reduction of $\left[{ }^{3} \mathrm{H}\right] \mathrm{DA}$ uptake with g

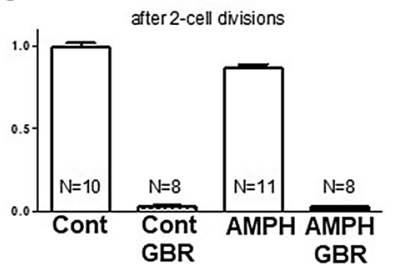

h

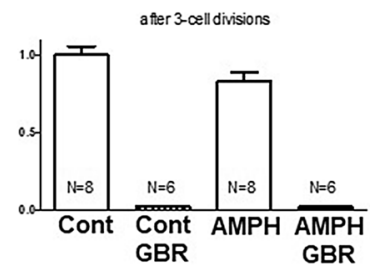

respect to samples pretreated with control solution only after $15 \mathrm{~h} \mathrm{(e)}$. GBR 12935 completely blocked $\left[{ }^{3} \mathrm{H}\right] \mathrm{DA}$ uptake in both AMPH- or control-pretreated samples $(\mathbf{a}-\mathbf{h})$. Graphs show average values of 3 independent experiments and $\mathrm{N}$ represents the total number of wells tested per sample. Data from each graph passed at least one of the 3 normality tests performed (KS, Shapiro-Wilk and D'agostino-Pearson omnibus test) with $\alpha=0.05$. Statistic analysis was performed using one-way ANOVA, Bonferroni's Multiple Comparison test $(* \mathrm{p} \leq 0.0001$ AMPH vs Cont) 


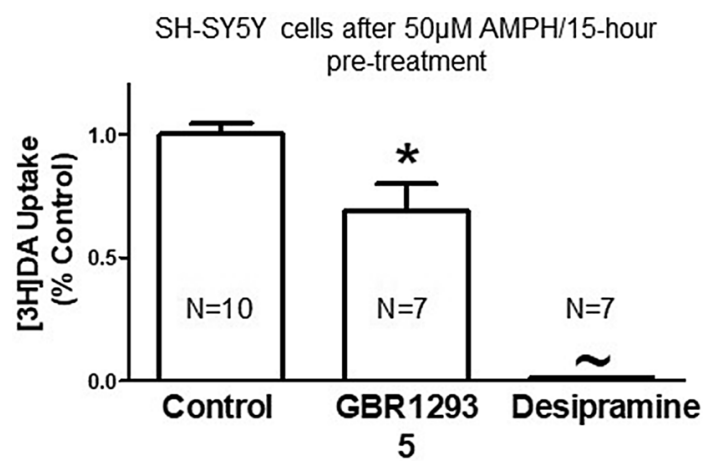

Fig. 2 DA uptake in SH-SY5Y cells is efficiently blocked by desipramine rather then GBR12935. SH-SY5Y cells were treated with retinoic acid for 5 days, then washed 3 times and incubated with $20 \mathrm{nM}$ $\left[{ }^{3} \mathrm{H}\right] \mathrm{DA}$ alone or $20 \mathrm{nM}\left[{ }^{3} \mathrm{H}\right] \mathrm{DA}$ and $100 \mathrm{nM}$ GBR 12935 or $20 \mathrm{nM}$ $\left[{ }^{3} \mathrm{H}\right] \mathrm{DA}$ and $100 \mathrm{nM}$ desipramine. Desipramine caused a $98 \pm 0.002 \%$ reduction in DA uptake whereas, GBR 12935 caused only $31 \pm 0.3 \%$ reduction. Graph represents average values of 3 independent experiments and $\mathrm{N}$ represents the total number of wells tested per sample. Data passed KS $(\alpha=0.05)$ and Shapiro-Wilk $(\alpha=0.05)$ normality tests. Statistic analysis was performed using one-way ANOVA, Bonferroni's Multiple Comparison test $(*$ and $\sim p \leq 0.005$ GBR12935 or desipramine vs Control, respectively) effects induced by AMPH were conserved in other cell types, we used the human neuroblastoma cell line SHSY5Y which have been shown to endogenously expresses DAT as well as NET [26-28]. To test if prolonged AMPH pretreatments generate long-term effects on DAT activity also in SH-SY5Y cells, we used the same experimental paradigm used for the LLC-PK1 cells with the addition of one extra step. After the $15 \mathrm{~h}$ of AMPH pretreatment, cells were incubated with $10 \mu \mathrm{M}$ retinoic acid (RA) for 5 days before performing the uptake assay. This step, as previously shown $[29,30]$, generates a higher number of differentiated neurons. Our pilot data showed that following RA-induced differentiation, 100 nM GBR12935, a specific DAT blocker, only partially blocked the DA uptake whereas, $100 \mathrm{nM}$ desipramine, a specific NET inhibitor, completely blocked DA uptake in the SH-SY5Y cells (Fig. 2). These results suggest that most of the DA in the SH-SY5Y cells is taken up by NET. Therefore, 100 $\mathrm{nM}$ desipramine were co-incubated with $\left[{ }^{3} \mathrm{H}\right] \mathrm{DA}$ to show the contribution of DAT/NET in our uptake experiments. We found that pretreatment with $50 \mu \mathrm{M}$ AMPH significantly reduced DA uptake to $55 \pm 0.14 \%(* \mathrm{p}<0.0001$; one-way ANOVA) with respect to control-treated cells

50 $\mu \mathrm{M}$ AMPH/15-hour pre-treatment in SH-SY5Ycells

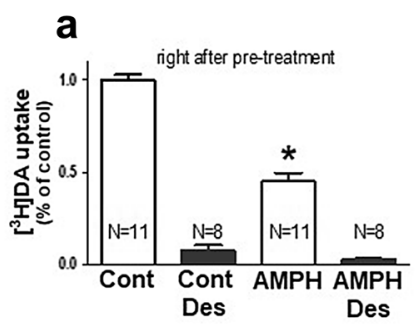

e

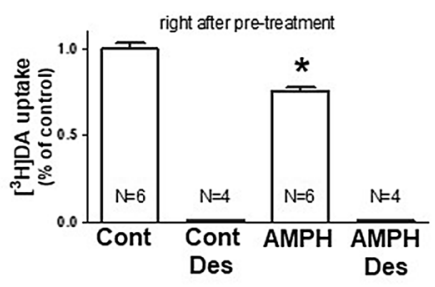

b

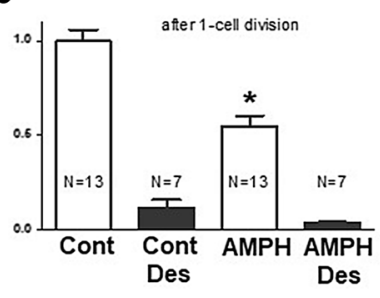

c

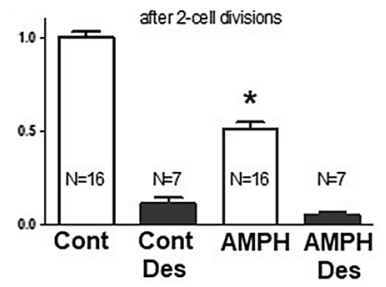

d

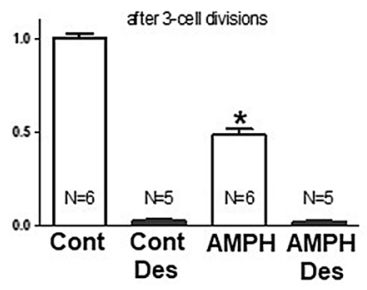

$1 \mu \mathrm{M}$ AMPH/15-hour pre-treatment in SH-SY5Ycells

f

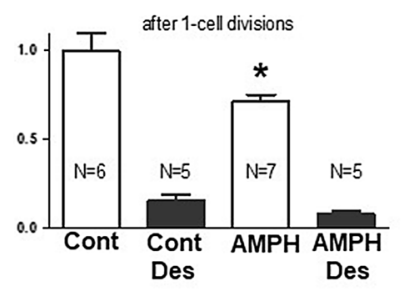

g

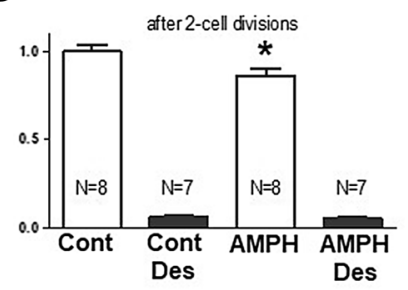

h

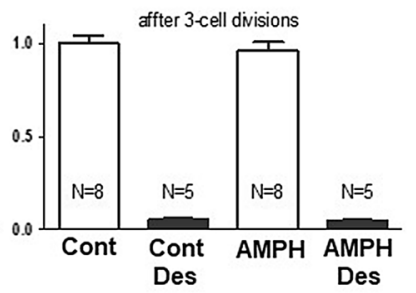

Fig. 3 Pretreatment with $50 \mu \mathrm{M}$ amphetamine (AMPH) caused significant reduction in DA uptake after 1-3 cell divisions whereas, 1 $\mu \mathrm{M}$ AMPH decreased DA uptake after 1-2 but not 3 cell divisions. Samples were pretreated with control (Cont), 50 (a-d) or 1 (e-h) $\mu \mathrm{M}$ AMPH for $15 \mathrm{~h}$. After 3 washes, cells were grown to go through 1-3 cell divisions, treated with retinoic acid for 5 days, then thoroughly washed and incubated for 5 min with $20 \mathrm{nM}\left[{ }^{3} \mathrm{H}\right] \mathrm{DA}$ alone or $20 \mathrm{nM}\left[{ }^{3} \mathrm{H}\right] \mathrm{DA}$ and $100 \mathrm{nM}$ desipramine (Des). Both concentrations of AMPH caused a statistically significant reduction of $\left[{ }^{3} \mathrm{H}\right]$
DA uptake up to 2-cell divisions with respect to samples pretreated with Cont solution $\left({ }^{*} \mathrm{p} \leq 0.0001\right.$; one-way ANOVA, Bonferroni's Multiple Comparison test). Des completely blocked $\left[{ }^{3} \mathrm{H}\right] \mathrm{DA}$ uptake in both AMPH- or Cont-pretreated samples. Data from A, B, C, G and $\mathrm{H}$ graphs passed the KS, Shapiro-Wilk and D'agostino-Pearson omnibus normality tests $(\alpha=0.05)$; $\mathbf{d}-\mathbf{f}$ graphs passed the KS normality test $(\alpha=0.05)$. Graphs represent average values of 3 independent experiments and $\mathrm{N}$ is the total number of wells tested per sample 
(Fig. 3a). This effect was maintained after $1-(45 \pm 0.2 \%)$, $2-(51 \pm 0.15 \%)$ and $3-(52 \pm 0.08 \%)$ cell divisions (Fig. 3b-d; *p $<0.0001$; one-way ANOVA). Similarly, pretreatments with $1 \mu \mathrm{M}$ AMPH caused a statistically significant $25 \pm 0.05 \%$ reduction $(* \mathrm{p}<0.0001$; oneway ANOVA) in DA uptake after 15-h AMPH pretreatment (Fig. 3e). Remarkably, we found that the effect of $1 \mu \mathrm{M}$ AMPH was also inherited in daughter cells after $1-(26 \pm 0.05 \%)$ and 2 -cell divisions $(15 \pm 0.1 \%)$, but not after 3-cell divisions (Fig. 3f-h; *p $<0.0001$; one-way ANOVA). $100 \mathrm{nM}$ desipramine, co-incubated with $20 \mathrm{nM}$ $\left[{ }^{3} \mathrm{H}\right] \mathrm{DA}$, caused $88-98 \%$ inhibition of uptake throughout our experiments (Fig. 3).

Although unlikely, the AMPH-induced reduction of DA uptake observed after the three cell divisions could be caused by residual AMPH not properly washed out from our samples. In this regards, it is worthwhile to note that the DA uptake experiments done after 1, 2 or 3 cell divisions, were performed after 1,3 or 4 days from the AMPH pretreatment in the LLC-PK1 cells, and after 6, 8 or 9 days in the SH-SY5Y cells. Moreover, before the uptake assay, cells were subjected to changes of media and thoroughly washed with KRH buffer. Nevertheless, we tested the possibility that residual AMPH concentrations were left in our samples by measuring the amount of AMPH present in the SH-SY5Y cells after $15 \mathrm{~h}$ of 50 $\mu \mathrm{M}$ AMPH pretreatment and washed three times as we did during the uptake experiments. Using Elisa kits, we found that the concentration of AMPH in cells pretreated with AMPH was $0.013 \pm 0.001 \mathrm{pM}$ and this value was comparable to the amount of AMPH, 0.01 $\pm 0.003 \mathrm{pM}$, measured in cells pretreated with control solution which never encountered AMPH. These results show that the AMPH-induced reduction of DA uptake measured in our assays (Figs. 1 and 3) is not caused by residual AMPH left in the cell cultures as proved by our Elisa data.

Taken together, these data suggest that prolonged AMPH exposure in cultured cells expressing hDAT and/ or hNET exogenously or endogenously causes long-term effects in the uptake activity of the transporters that are maintained during cell divisions.

\section{Prolonged Treatments with $\mathbf{5 0} \mu \mathrm{M}$ Amphetamine do not Affect Cell Viability}

Previous data showed that 24-h treatment with $3 \mathrm{mM}$ AMPH cause cell toxicity and consequent death in the SH-SY5Y cells [31]. In our study, we used much lower concentrations of AMPH ( 1 or $50 \mu \mathrm{M}$ ) for $15 \mathrm{~h}$. Nonetheless, we reasoned to test whether, under our experimental conditions, AMPH caused cell death. If that were the case, then the reduction of DA uptake observed after 15-h treatment and up to 3-cell divisions would be the result of a reduced number of DAT/ NET-expressing cells. Thus, during our uptake experiments, extra samples were used in parallel to assess cell viability and to count the number of SH-SY5Y cells that went through the 15 -h pretreatment with $50 \mu \mathrm{M}$ AMPH or control solution. Cell viability, assessed by trypan blue staining combined with an automated cell counter, was in the range of 99-100\% for both control- and AMPH-treated samples (Table 1). As shown in the same table, no difference in cell counting between the two groups was observed neither after 15-h or 1, 2, or 3-cell divisions. Moreover, imaging data showed that AMPH did not induce any obvious change in cell morphology in both SH-SY5Y and LLC-PK1 cells (data not shown). These results suggest that $50 \mu \mathrm{M}$ AMPH for 15 $\mathrm{h}$ do not cause cell death in both LLC-PK1 and SH-SY5Y cells.

\section{Prolonged Treatments with $50 \mu \mathrm{M}$ Amphetamine do not Change Intracellular ATP or ROS in SH-SY5Y Cells}

Administrations of high-dose (10-15 mg/kg) of AMPH and AMPH analogues in rodents increase reactive oxygen species (ROS) and decrease ATP levels [32]. Therefore, we tested whether the highest concentration of AMPH we used, $50 \mu \mathrm{M}$, altered ATP and/or ROS production. Using the CellTiter-Glo Assay kit (Promega) we measured the ATP

Table 1 Prolonged treatment with $50 \mu \mathrm{M}$ amphetamine do not affect cell viability

\begin{tabular}{|c|c|c|c|c|c|c|c|c|}
\hline & \multicolumn{2}{|c|}{ After 15 -h treatment } & \multicolumn{2}{|c|}{ After 1-cell division } & \multicolumn{2}{|c|}{ After 2-cell division } & \multicolumn{2}{|c|}{ After 3-cell division } \\
\hline & Cell count & Viability (\%) & Cell count & Viability (\%) & Cell count & Viability (\%) & Cell count & Viability (\%) \\
\hline Control & $\begin{array}{l}197,000 \pm \\
6000\end{array}$ & 100 & $\begin{array}{c}417,000 \pm \\
18,000\end{array}$ & 100 & $\begin{array}{c}720,000 \pm \\
20,000\end{array}$ & 99 & $\begin{array}{c}1,140,000 \pm \\
160,000\end{array}$ & 99 \\
\hline $50 \mu \mathrm{m}$ AMPH & $\begin{array}{c}192,000 \pm \\
7000\end{array}$ & 100 & $\begin{array}{c}430,000 \pm \\
10,000\end{array}$ & 99 & $\begin{array}{c}707,000 \pm \\
30,000\end{array}$ & 100 & $\begin{array}{c}1,045,000 \pm \\
55,000\end{array}$ & 99 \\
\hline
\end{tabular}

SH-SY5Y cells were pretreated with control or amphetamine (AMPH) for $15 \mathrm{~h}$. Some samples were differenciated for 5 days with retinoic acid (RA) and then used for cell counting and viability tests (after 15-h treatment), whereas others were grown to go 1-3 cell divisions, treated with RA to induce neuronal differentiation and then tested for viability and cell counting. Data are representative of 3 independent experiments and in each experiment, samples were tested in duplicates 

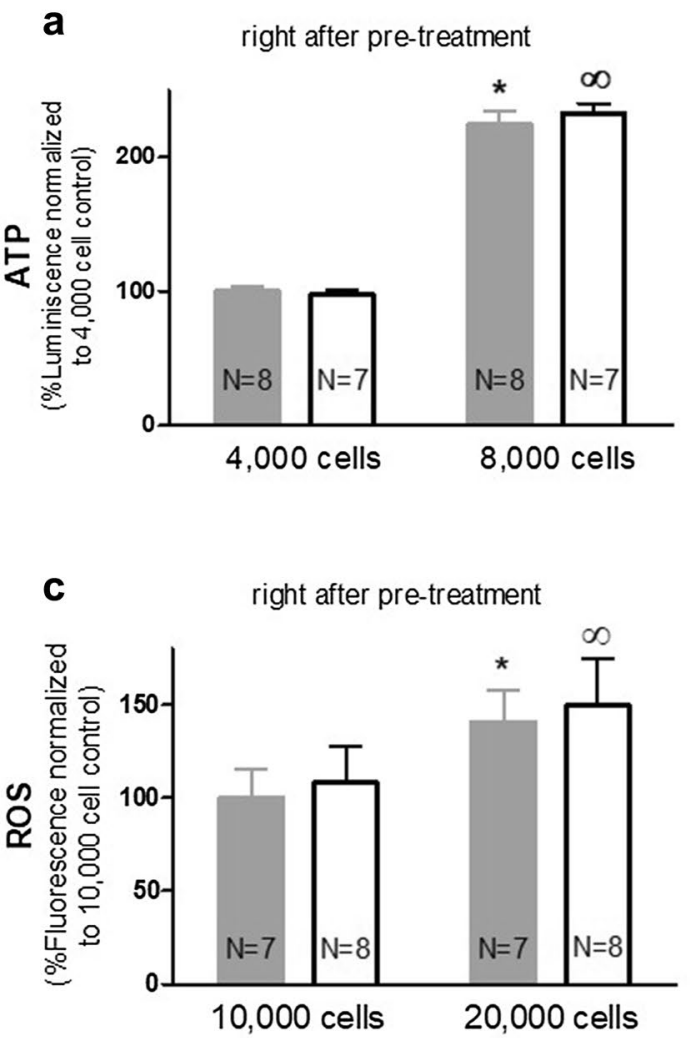

Fig. 4 Prolonged treatments with $50 \mu \mathrm{M}$ amphetamine do not alter intracellular concentrations of ATP or ROS. SH-SY5Y cells were pretreated with control or amphetamine (AMPH). After $15 \mathrm{~h}$, cells were washed 3 times and the intracellular concentrations of ATP (a) or ROS (c) were measured. In another subgroup of samples, ATP or ROS were measured after the cells went through 1-cell division (bd). Graphs represent average values of 2 independent experiments and $\mathrm{N}$ is the total number of repetitions per sample. The number of cells in the $\mathrm{X}$ axis represent the amount of cells seeded in each well.

levels in SH-SY5Y cells right after $15 \mathrm{~h}$ pretreatment with $50 \mu \mathrm{M}$ AMPH or after 1-cell division, and found no change with respect to control-treated cells (Fig. 4a, b, compare white bars with gray bars). On the other hand, the ATP values doubled in samples containing twice as much the number of cells $\left(* p<0.001\right.$ and ${ }^{\infty} p<0.001$; one-way ANOVA, Bonferroni post-test). These experiments show that while the luminescence signal, which is representative of intracellular ATP, is proportional to the number of cells tested, the treatment with AMPH does not change the intracellular levels of ATP.

Next, we tested whether prolonged treatments with $50 \mu \mathrm{M}$ AMPH changed the intracellular amount of ROS by using the $2^{\prime}, 7^{\prime}$-dichlorodihydroflorescein diacetate $\left(\mathrm{H}_{2}\right.$-DCFDA) molecular probe (Invitrogen). $\mathrm{H}_{2}$-DCFDA is cell permeant and, once inside the cell, its acetate groups are removed by intracellular esterases. If ROS are available, oxidation occurs and the fluorescent $2^{\prime}, 7^{\prime}$-dichlorofluorescin (DCF) is b
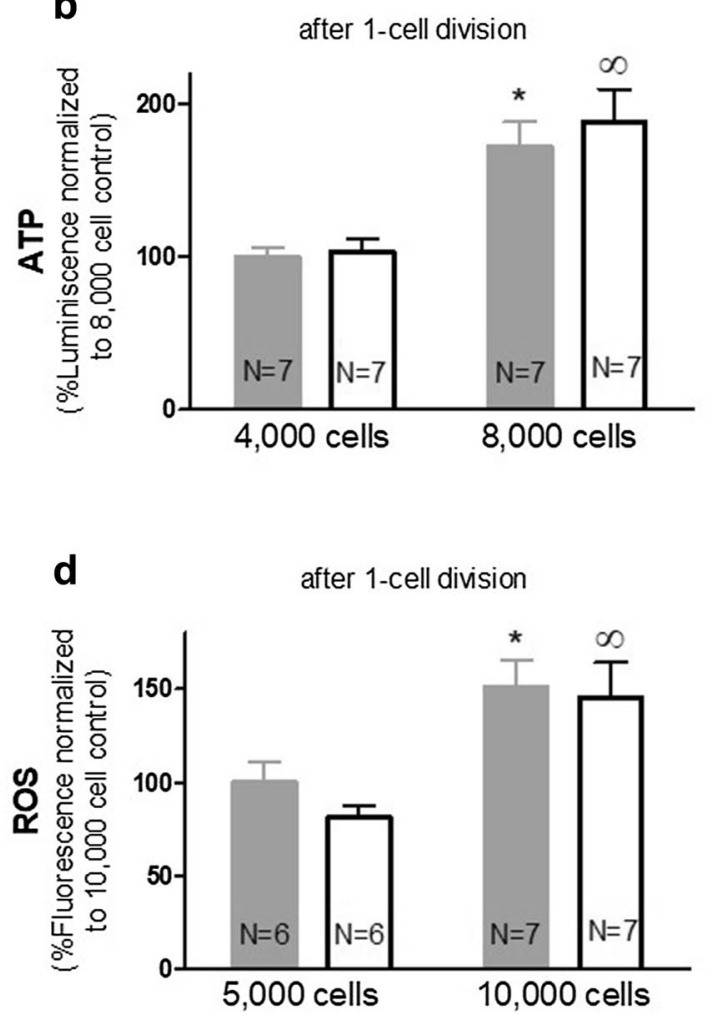

Data in graphs B and D passed KS, Shapiro-Wilk and D'agostinoPearson omnibus tests with $\alpha=0.05$; whereas, data in A and $\mathrm{C}$ graphs passed KS and Shapiro-Wilk tests with $\alpha=0.05$. The oneway ANOVA-Bonferroni's Multiple Comparison test showed significant differences among the number of cells seeded but not between treatments. ${ }^{*} \mathrm{p} \leq 0.0001$ for Cont -8000 vs Cont $-4000(\mathbf{a}, \mathbf{b})$ and Cont20,000/10,000 vs Cont-10,000/5000 cells (c, d). ${ }^{\infty} \mathrm{p} \leq 0.0001$ for AMPH-8000 vs AMPH-4000 (a, b) and AMPH-20,000/10,000 vs AMPH-10,000/5000 cells $(\mathbf{c}, \mathbf{d})$

produced. Thus, an increase in fluorescence reflects higher amounts of intracellular ROS. As shown in Fig. 4c and d, no significant difference was observed between control- and AMPH-treated SH-SY5Y cells neither after $15 \mathrm{~h}$ treatment nor 1-cell division (compare white bars with gray bars). However, also in this case, a significant increase of ROS levels was detected in samples containing a higher number of cells $\left({ }^{*} \mathrm{p}<0.001\right.$ and ${ }^{\infty} \mathrm{p}<0.001$; one-way ANOVA, Bonferroni post-test) confirming the efficacy of the probe. Taken together, these data show that, when exposed to 50 $\mu \mathrm{M}$ AMPH for $15 \mathrm{~h}$, the SH-SY5Y cells do not exhibit significant changes in ROS or ATP. 


\section{Discussion}

Since it was discovered, AMPH has been used to treat a variety of mental and physical conditions. Currently, low concentrations of AMPH $(5-30 \mathrm{mg} / \mathrm{pill})$ are successfully used to treat patients affected with narcolepsy, chronic fatigue syndrome and those affected with attention deficit disorders. On the other hand, data suggesting systemic toxicity caused by elevated and prolonged use of AMPH (260-1000 mg) have been reported both in animal models and postmortem human samples [33]. These opposite outcomes suggest that the concentration of AMPH is a crucial factor in determining the final effects of AMPH.

It is well established that AMPH increases neurotransmission of DA and NE by competing with the transport of these catecholamines and by displacing their storage vesicles. As a matter of fact, DAT and NET are direct targets of AMPH [34]. Moreover, previous reports have demonstrated that AMPH also alters the amount of DA removed from the synaptic cleft by changing the number of DAT at the plasma membrane [35]. For example, in rat striatal synaptosomes $5 \mu \mathrm{M}$ AMPH increased surface DAT within $30 \mathrm{~s}$ and up 1-min following drug exposure [14]. On the other hand, 1-h treatment with $2 \mu \mathrm{M}$ AMPH caused loss of DAT on the cell membrane which resulted in $40 \%$ reduction of DA uptake [16]. Under these conditions, the reduction of DA uptake caused by AMPH was DAT mediated and not produced by passive membrane diffusion of AMPH, since co-incubation with cocaine, a specific DAT blocker, prevented the AMPHinduced effects on DA uptake. All these data demonstrate that the alterations caused by short treatments of AMPH on DAT function have been well established. However, no study has been performed to test the effects that prolonged AMPH treatments have on the catecholamine transporters. Here we investigated the effect of 15 -h continuous exposure of AMPH in cells expressing DAT and/or NET. We used 1 and $50 \mu \mathrm{M}$ of AMPH because previous data showed that a single dose between 260 and $1000 \mathrm{mg}$ methamphetamine (METH), which are the range of doses used by METH abusers, produce a pick of 7.5-28.8 $\mu \mathrm{M}$ METH in human blood [24]. And since the brain:serum ratio for AMPH measured in rats is about 7:1 [25], we calculated that the amount of AMPH in the brain of AMPH abuser is about 50-200 $\mu \mathrm{M}$. Similarly, people who use 5-30 mg AMPH as therapeutic treatment are predicted to get about $1-6 \mu \mathrm{M}$ AMPH in their brain.

To ensure that our results were representative of AMPH acting specifically at the catecholamine transporters, we first investigated the effects that 15 -h pretreatments with 1 or $50 \mu \mathrm{M}$ AMPH produced in LLC-PK1 cells stably expressing hDAT. At the end of the treatment and after thoroughly washing out AMPH from the samples, we found that both concentrations caused a significant and comparable decrease in DAT activity as measured by quantifying the radioactive $\left[{ }^{3} \mathrm{H}\right] \mathrm{DA}$ accumulated inside the cells. Previous studies reported that acute or short-lasting treatments with AMPH reduces DAT activity by reallocating the transporter from the plasma membrane into intracellular compartments [16, $20,21,35]$. We can speculate that also 15 -h pretreatments with AMPH lower the capability of cells to reuptake DA by increasing DAT internalization from the cell membrane. Interestingly though, we observed that the reduced DA uptake observed in LLC-PK1 cells pretreated with 50 but not $1 \mu \mathrm{M}$ AMPH was maintained up to three cell divisions, suggesting therefore, that continuous exposure to $50 \mu \mathrm{M}$ AMPH also produce a non-previously reported effect which is retained during mitosis.

The LLC-PK1 cells used in our study were engineered to stably express hDAT. Thus, although integrated into the cell genome, the hDAT gene is not normally expressed in these cells. For this reason, we investigated whether the long-term effects generated by AMPH were also observed in a more physiologically relevant cell line. We chose to use the SHSY5Y cells which are derived from human neuroblastoma cells. These cells contain both epithelial and primordial neuronal cells. The neuronal-type cells are in an early neuronal differentiation stage, characterized by the low presence of markers specific for cholinergic [36, 37], adrenergic and dopaminergic neurons including tyrosine hydroxylase [38], VMAT and DAT [26, 27, 39]. However, after treatment with RA, the SH-SY5Y cells exhibit morphological and biochemical parameters similar to those observed in differentiated neurons [29, 40, 41]. Thus, the SH-SY5Y cells are a good model to study if and how drugs affect neuronal differentiation.

Previous studies showed that 4-11 days of RA treatment increase the number of catecholaminergic neurons in the SH-SY5Y cells [42]. Accordingly, we found that after a 5-day RA treatment, SH-SY5Y cells efficiently accumulated $\left[{ }^{3} \mathrm{H}\right] \mathrm{DA}$ and, while the NET specific inhibitor desipramine [43] completely blocked DA uptake, the GBR12935 blocker, which has a higher affinity to DAT than NET [44], only partially diminished DA uptake. This result may have two implications: (I) the RA-treated SH-SY5Y cells express only NET and the reduced ability of $100 \mathrm{nM}$ GBR 12935 to block DA uptake (Fig. 2) is due to the reduced affinity this blocker has for NET with respect to DAT; or (II) the RA-treated SH-SY5Y cells express more adrenergic neurons (NET-positive cells) than dopaminergic neurons (DATpositive cells). In this second scenario, the $30 \%$ inhibition of DA uptake observed in presence of $100 \mathrm{nM}$ GBR12935 (Fig. 2) is representative of the reduced number of DATexpressing neurons in our cultures. Nevertheless, our data show that $100 \mathrm{nM}$ desipramine effectively block DA uptake in the SH-SY5Y cells. 
The most important result of our study is that both 1 and $50 \mu \mathrm{M}$ AMPH pretreatments reduced the transportmediated DA uptake in SH-SY5Y daughter cells, and this effect occurred several days after the AMPH pretreatment. In fact, after the AMPH pretreatment and before the uptake assay, cells went through 1 to 3 cell divisions followed by a 5-day incubation with RA. This last step was required to increase the number of differentiated catecholaminergic neurons, i.e. to increase the number of neurons expressing DAT or NET. These results suggest that prolonged exposure to AMPH during development, when neural progenitor cells are formed, may change the asset of catecholaminergic neurons by reducing the number of neurons expressing DAT/NET or, alternatively, decreasing the expression of catecholamine transporters. One implication of these data is that prolonged use of AMPH during pregnancy might affect neuronal asset in the fetus. However, further experiments are needed to validate these conclusions.

Although unlikely, our experiments left open the possibility that residual concentrations of AMPH, after the 15-h pretreatment, were left behind in the cells. For this reason, we used an Elisa kit to measure the amount of AMPH and found no difference between control- and AMPH-pretreated cells. Therefore, we concluded that the AMPH-induced long-term effects seen in our experiments occurred during the 15-h exposure to the drug but, somehow, was maintained after the removal of AMPH.

We also investigated whether the reduction of DA uptake seen in daughter cells could be the result of cell death or changes in ROS and ATP as previous reports showed that high concentrations of AMPH for $24 \mathrm{~h}$ reduce viability of cultured cells [31]. The concentrations of AMPH used in our study, 1 and $50 \mu \mathrm{M}$, are much lower than those reported to be lethal in cell cultures $(100 \mu \mathrm{M})$; yet we investigated whether $50 \mu \mathrm{M}$ AMPH could induce cell death under our experimental conditions. We found that cells treated with AMPH for $15 \mathrm{~h}$ had $99-100 \%$ viability, presented no morphological modification and showed no change in cell counting yielded right after the pretreatment or after the various cell divisions with respect to control-treated cells. Moreover, the intracellular levels of ATP or ROS in SH-SY5Y were not changed by 15 -h treatment with $50 \mu \mathrm{M}$ AMPH (Fig. 4). Thus, our data demonstrate that the reduction of DA uptake we measured in our experiments is not due to residual concentrations of AMPH in the cells nor to AMPH-induced cell toxicity, rather they suggest that prolonged treatments with $1-50$ $\mu \mathrm{M}$ AMPH may activate unknown mechanisms that can be inherited during cell divisions.

In conclusion, our results suggest that prolonged AMPH exposure during neuronal differentiation may affect the function/expression of DAT/NET in mature neurons. In fact, the experiments performed with SH-SY5Y cells were designed in a way that the treatment with AMPH preceded neuronal differentiation, i.e. when the SH-SY5Y cells exhibit features typical of an early neuronal differentiation stage or neural progenitor cells [36-39], but DAT/NET function was measured after RA-induced differentiation, i.e. when SH-SY5Y cells exhibit both morphological and biochemical features similar to those observed in differentiated neurons [29, 40-42]. Thus, we speculate that prolonged AMPH exposures during proliferation and differentiation of primordial neuronal cells change DA reuptake in mature neurons.

Funding This study was funded by National Institute on Drug Abuse (Grant No. DA042156).

Open Access This article is licensed under a Creative Commons Attribution 4.0 International License, which permits use, sharing, adaptation, distribution and reproduction in any medium or format, as long as you give appropriate credit to the original author(s) and the source, provide a link to the Creative Commons licence, and indicate if changes were made. The images or other third party material in this article are included in the article's Creative Commons licence, unless indicated otherwise in a credit line to the material. If material is not included in the article's Creative Commons licence and your intended use is not permitted by statutory regulation or exceeds the permitted use, you will need to obtain permission directly from the copyright holder. To view a copy of this licence, visit http://creativecommons.org/licenses/by/4.0/.

\section{References}

1. Walters SH, Taylor IM, Shu Z, Michael AC (2014) A novel restricted diffusion model of evoked dopamine. ACS Chem Neurosci 5(9):776-783

2. Jones SR, Gainetdinov RR, Wightman RM, Caron MG (1998) Mechanisms of amphetamine action revealed in mice lacking the dopamine transporter. J Neurosci 18(6):1979-1986

3. Pramod AB, Foster J, Carvelli L, Henry LK (2013) SLC6 transporters: Structure, function, regulation, disease association and therapeutics. Mol Aspects Med 34(2-3):197-219

4. Ingram SL, Prasad BM, Amara SG (2002) Dopamine transportermediated conductances increase excitability of midbrain dopamine neurons. Nat Neurosci 5(10):971-978

5. Carvelli L, McDonald PW, Blakely RD, DeFelice LJ (2004) Dopamine transporters depolarize neurons by a channel mechanism. Proc Natl Acad Sci 101(45):16046-16051

6. Koob GF, Bloom FE (1988) Cellular and molecular mechanisms of drug dependence. Science 242(4879):715-723

7. Di Chiara G, Imperato A (1988) Drugs abused by humans preferentially increase synaptic dopamine concentrations in the mesolimbic system of freely moving rats. Proc Natl Acad Sci USA 85(14):5274-5278

8. Wozniak KM, Pert A, Mele A, Linnoila M (1991) Focal application of alcohols elevates extracellular dopamine in rat brain: a microdialysis study. Brain Res 540(1-2):31-40

9. Ritz MC, Lamb RJ, Goldberg SR, Kuhar MJ (1988) Cocaine self-administration appears to be mediated by dopamine uptake inhibition. Prog Neuropsychopharmacol Biol Psychiatry 12(2-3):233-239 
10. Sulzer D (2011) How addictive drugs disrupt presynaptic dopamine neurotransmission. Neuron 69(4):628-649

11. Sulzer D, Sonders MS, Poulsen NW, Galli A (2005) Mechanisms of neurotransmitter release by amphetamines: a review. Prog Neurobiol 75(6):406-433

12. Carvelli L, Matthies DS, Galli A (2010) Molecular mechanisms of amphetamine actions in Caenorhabditis elegans Mol Pharmacol 78(1):151-156

13. Kuczenski R, Segal DS (1997) Effects of methylphenidate on extracellular dopamine, serotonin, and norepinephrine: comparison with amphetamine. J Neurochem 68(5):2032-2037

14. Johnson LA, Furman CA, Zhang M, Guptaroy B, Gnegy ME (2005) Rapid delivery of the dopamine transporter to the plasmalemmal membrane upon amphetamine stimulation. Neuropharmacology 49(6):750-758

15. Furman CA, Chen R, Guptaroy B, Zhang M, Holz RW, Gnegy MJ (2009) Dopamine and amphetamine rapidly increase dopamine transporter trafficking to the surface: live-cell imaging using total internal reflection fluorescence microscopy. Neuroscience 29(10):3328-3336

16. Saunders C, Ferrer JV, Shi L, Chen J, Merrill G, Lamb ME, LeebLundberg LM, Carvelli L, Javitch JA, Galli A (2000) Amphetamine-induced loss of human dopamine transporter activity: an internalization-dependent and cocaine-sensitive mechanism. Proc Natl Acad Sci USA 97(12):6850-6855

17. Carvelli L, Morón JA, Kahlig KM, Ferrer JV, Sen N, Lechleiter JD, Leeb-Lundberg LM, Merrill G, Lafer EM, Ballou LM, Shippenberg TS, Javitch JA, Lin RZ, Galli A (2002) PI 3-kinase regulation of dopamine uptake. J Neurochem 81(4):859-869

18. Gulley JM, Doolen S, Zahniser NR (2002) Brief, repeated exposure to substrates down-regulates dopamine transporter function in Xenopus oocytes in vitro and rat dorsal striatum in vivo. J Neurochem 83(2):400-411

19. Boudanova E, Navaroli DM, Stevens Z, Melikian HE (2008) Dopamine transporter endocytic determinants: carboxy terminal residues critical for basal and PKC-stimulated internalization. Mol Cell Neurosci 39(2):211-217

20. Hong WC, Amara SG (2013) Differential targeting of the dopamine transporter to recycling or degradative pathways during amphetamine- or PKC-regulated endocytosis in dopamine neurons. FASEB J 27(8):2995-3007

21. Wheeler DS, Underhill SM, Stolz DB, Murdoch GH, Thiels E, Romero G, Amara SG (2015) Amphetamine activates Rho GTPase signaling to mediate dopamine transporter internalization and acute behavioral effects of amphetamine. Proc Natl Acad Sci USA 112(51):E7138-E7147

22. German CL, Hanson GR, Fleckenstein AE (2012) Amphetamine and methamphetamine reduce striatal dopamine transporter function without concurrent dopamine transporter relocalization. J Neurochem 123(2):288-297

23. Steinkellner T, Mus L, Eisenrauch B, Constantinescu A, Leo D, Konrad L, Rickhag M, Sørensen G, Efimova EV, Kong E, Willeit M, Sotnikova TD, Kudlacek O, Gether U, Freissmuth M, Pollak DD, Gainetdinov RR, Sitte HH (2014) In vivo amphetamine action is contingent on $\alpha$ CaMKII. Neuropsychopharmacology 39(11):2681-2693

24. Melega WP, Cho AK, Harvey D, Lacan G (2007) Methamphetamine blood concentrations in human abusers: application to pharmacokinetic modeling. Synapse 61:216-220

25. Riviere GJ, Gentry WB, Owens SM (2000) Disposition of methamphetamine and its metabolite amphetamine in brain and other tissues in rats after intravenous administration. J Pharmacol Exp Ther 292:1042-1047

26. Yang W, Tiffany-Castiglioni E (2005) The bipyridyl herbicide paraquat produces oxidative stress-mediated toxicity in human neuroblastoma SH-SY5Y cells: relevance to the dopaminergic pathogenesis. J Toxicol Environ Health A 68(22):1939-1961

27. Jiang H, Jiang Q, Feng J (2004) Parkin increases dopamine uptake by enhancing the cell surface expression of dopamine transporter. J Biol Chem 279(52):54380-54386

28. Brüss M, Hammermann R, Brimijoin S, Bönisch H (1995) Antipeptide antibodies confirm the topology of the human norepinephrine transporter. J Biol Chem 270(16):9197-9201

29. Påhlman S, Ruusala AI, Abrahamsson L, Mattsson ME, Esscher T (1984) Retinoic acid-induced differentiation of cultured human neuroblastoma cells: a comparison with phorbolester-induced differentiation. Cell Diff 14(2):135-144

30. Korecka JA, van Kesteren RE, Blaas E, Spitzer SO, Kamstra JH, Smit A, Swaab DF, Verhaagen J, Bossers K (2013) Phenotypic characterization of retinoic acid differentiated SH-SY5Y cells by transcriptional profiling. PLoS ONE 8(5):e63862

31. Feio-Azevedo R, Costa VM, Ferreira LM, Branco PS, Pereira FC, Bastos ML, Carvalho F, Capela JP (2017) Toxicity of the amphetamine metabolites 4-hydroxyamphetamine and 4-hydroxynorephedrine in human dopaminergic differentiated SH-SY5Y cells. Toxicol Lett 269:65-76

32. Brown JM, Yamamoto BK (2003) Effects of amphetamine on mitochondrial function: role of free radicals and oxidative stress. Pharmacol Ther 99(1):45-53

33. Berman SM, Kuczenski R, McCracken JT, London ED (2009) Potential adverse effects of amphetamine treatment on brain and behavior: a review. Mol Psychiatry 14(2):123-142

34. Sitte HH, Freissmuth M (2015) Amphetamines, new psychoactive drugs and the monoamine transporter cycle. Trends Pharmacol Sci 36(1):41-50

35. Melikian HE (2004) Neurotransmitter transporter trafficking: endocytosis, recycling, and regulation. Pharmacol Ther 104(1):17-27

36. Biedler JL, Roffler-Tarlov S, Schachner M, Freedman LS (1978) Multiple neurotransmitter synthesis by human neuroblastoma cell lines and clones. Can Res 38(11):3751-3757

37. Gilany K, Van Elzen R, Mous K, Coen E, Van Dongen W, Vandamme S, Gevaert K, Timmerman E, Vandekerckhove J, Dewilde S, Van Ostade X, Moens L (2008) The proteome of the human neuroblastoma cell line SH-SY5Y: an enlarged proteome. Biochem Biophys Acta 1784(7-8):983-985

38. Ross RA, Biedler JL (1985) Presence and regulation of tyrosinase activity in human neuroblastoma cell variants in vitro. Can Res 45(4): 1628-1632

39. Pan T, Xie W, Jankovic J, Le W (2005) Biological effects of pramipexole on dopaminergic neuron-associated genes: relevance to neuroprotection. Neurosci Lett 377(2):106-109

40. Lopes FM, Schröder R, da Frota ML Jr, Zanotto-Filho A, Müller CB, Pires AS, Meurer RT, Colpo GD, Gelain DP, Kapczinski F, Moreira JC, Fernandes Mda C, Klamt F (2010) Comparison between proliferative and neuron-like SH-SY5Y cells as an in vitro model for Parkinson disease studies. Brain Res 1337:85-94

41. López-Carballo G, Moreno L, Masiá S, Pérez P, Barettino D (2002) Activation of the phosphatidylinositol 3-kinase/Akt signaling pathway by retinoic acid is required for neural differentiation of SH-SY5Y human neuroblastoma cells. J Biol Chem 277(28):25297-25304

42. Lopes FM, da Motta LL, De Bastiani MA, Pfaffenseller B, Aguiar BW, de Souza LF, Zanatta G, Vargas DM, Schönhofen P, Londero GF, de Medeiros LM, Freire VN, Dafre AL, Castro MA, Parsons RB, Klamt F (2017) RA Differentiation enhances dopaminergic features, changes redox parameters, and increases dopamine transporter dependency in 6-hydroxydopamine-induced neurotoxicity in SH-SY5Y cells. Neurotox Res 31(4):545-559 
43. Ordway GA, Stockmeier CA, Cason GW, Klimek V (1997) Pharmacology and distribution of norepinephrine transporters in the human locus coeruleus and raphe nuclei. J Neurosci 5:1710-1719

44. Dutta AK, Davis MC, Fei XS, Beardsley PM, Cook CD, Reith ME (2002) Expansion of structure-activity studies of piperidine analogues of 1-[2-(diphenylmethoxy)ethyl]-4-(3-phenylpropyl) piperazine (GBR 12935) compounds by altering substitutions in the $N$-benzyl moiety and behavioral pharmacology of selected molecules. J Med Chem 45(3):654-662
Publisher's Note Springer Nature remains neutral with regard to jurisdictional claims in published maps and institutional affiliations. 